\title{
Correction of Interleukin-2 Production in Patients with Systemic Lupus Erythematosus by Removal of Spontaneously Activated Suppressor Cells
}

\author{
Mariana Linker-Israeli, Antony C. Bakke, Francisco P. Quismorio, Jr., and David A. Horwitz \\ Clinical Immunology and Rheumatic Disease Section, Department of Medicine, University of Southern California School of Medicine, \\ Los Angeles, California 90033
}

\begin{abstract}
Interleukin-2 (IL-2) production in vitro is depressed in systemic lupus erythematosus (SLE) patients. It is not known whether this abnormality is caused by a defect in the producer lymphocytes or by excessive suppression. We report that removal of OKT8 (Leu 2a)+ cells increased the IL-2 production by in vitro-stimulated lymphocytes to normal or above normal levels in 19 of 21 SLE patients. This increase was more apparent in those patients with clinically inactive disease and/or receiving $<7.5 \mathrm{mg}$ of prednisone. Removal of OKT8+ cells from normals did not significantly increase IL-2 activity. SLE, but not normal, OKT8+ cells decreased IL-2 production when added back to autologous OKT8-depleted cells. In some experiments, OKT8+ cells from normal donors also suppressed IL-2 production in SLE. This result suggests that the defect in IL-2 production is complex and may involve multiple cell interactions. Three lines of evidence suggest that the SLE OKT8+ cells actively inhibit the production of IL-2 rather than passively absorb this lymphokine: (a) only $3.2 \%$ of SLE lymphocytes expressed IL-2 receptors as detected with anti-Tac; $(b)$ freshly prepared SLE lymphocytes did not absorb IL-2; and (c) cellfree supernatants from SLE OKT8+ cells inhibited IL-2 production, but not IL-2 activity. Double-labeling studies by flow cytometry revealed that $19.3 \%$ of SLE OKT8+ cells were also Ia-positive, and $\sim 33 \%$ co-expressed the natural killer cell marker, HNK-1 (Leu 7). Removal of Leu 7+ cells also significantly elevated IL-2 production in SLE. These studies suggest that one or more circulating mononuclear cell subsets in SLE patients can suppress IL-2 production and that one subset may possibly belong to a non-T, non-B "third mononuclear population."
\end{abstract}

\section{Introduction}

Systemic lupus erythematosus (SLE) ${ }^{1}$ is a disorder characterized by $B$ lymphocyte hyperactivity resulting in increased immu-

Address requests for reprints to Dr. Linker-Israeli, Clinical Immunology and Rheumatic Disease Section, University of Southern California School of Medicine, 2025 Zonal Avenue HMR\#711, Los Angeles, CA 90033.

Received for publication 18 April 1984 and in revised form 25 October 1984.

1. Abbreviations used in this paper: FITC, fluorescein isothiocyanate; HNK-1, natural killer cell marker; IL-2, interleukin-2; PBM, peripheral blood mononuclear cells; PE, phycoerythrin; PHA, phytohemagglutinin; SLE, systemic lupus erythematosus.

J. Clin. Invest.

(C) The American Society for Clinical Investigation, Inc.

0021-9738/85/02/0762/07 \$1.00

Volume 75, February 1985, 762-768 noglobulin and autoantibody formation. The initial factors responsible for the increased antibody formation are poorly understood. Decreased numbers of T suppressor cells (1) and suppressor function $(2,3)$ have been proposed as the causes for this defect. However, many SLE patients have relatively increased circulating OKT8+ cells $(4,5)$, and some workers have found suppressor cell activity intact (6).

Interleukin-2 (IL-2) is required for clonal expansion of both helper and suppressor cells (7). Recently, we and others $(8,9)$ have reported decreased in vitro production of IL-2 by blood lymphocytes in SLE. This decrease could be explained by a defective producer cell or by the presence of an inhibitory cell. In this article, we report that the principal mechanism for decreased IL-2 production in SLE is active inhibition. Removal of an OKT8+ subset elevated IL-2 levels to normal or abovenormal levels in 19 of 21 patients with both active and inactive disease. Removal of natural killer cell marker (HNK-1)+ cells also corrected IL-2 production. Evidence will be presented to show that the OKT $8+$ cells actively suppressed IL- 2 production rather than passively absorbed newly released lymphokine.

\section{Methods}

21 patients who fulfilled the 1982 revised criteria of the American Rheumatism Association for SLE (10) were selected from the inpatient and outpatient services of our section. The clinical and serologic features of the patients are shown in Table I. All were women whose ages ranged from 19 to $50 \mathrm{yr}$ with a mean of $29.8 \pm 1.6 \mathrm{yr}$. 14 patients were Hispanic-Americans, 3 were Caucasians, and 4 were Blacks. The duration of the disease ranged from 0.4 to $18 \mathrm{yr}$ with a mean of $5.4 \pm 0.9 \mathrm{yr}$

The patients were divided into two groups: group I -5 patients with stable or inactive disease; group II-16 patients with manifestations of both clinical and serologic activity. Clinically active disease was defined as the involvement of three or more organs at the time of the study (see footnotes to Table I).

Active serology was defined as the presence of two or more of the following: low serum complement (CH50) (normal values $=480-960$ U), a positive Crithidia luciliae test for anti-DNA antibodies (normal value $=<1: 10$ ), and elevated levels of serum cryoglobulins (normal value $\leq 3 \mathrm{mg} / \mathrm{dl}$ ). Duration of disease and dose of prednisone are also mentioned in this table.

After the blood specimens were obtained, the prednisone dose was increased in nine patients of group II. Paired controls were normal donors matched for sex, age, and ethnic background.

Monoclonal antibodies. The following monoclonal antibodies were used in these studies: OKT8 and OKT4 purchased from Ortho Pharmaceutical, Raritan NJ; Leu 2, purchased from Becton, Dickinson \& Co., Mountainview, CA; HNK-1 (Leu 7) generously provided by Dr. Toro Abo, Birmingham, AL; anti-Ia, generously provided by Dr. Ralph Reisfeld, San Diego, CA: fluorescein-conjugated anti-Ia (a gift of Becton, Dickinson \& Co.); anti-Tac, generously provided by Dr. Thomas Waldman; and Mo.2, purchased from Bethesda Research Laboratories, Gaithersburg, MD. 
Table I. Clinical and Serologic Features of SLE Patients and Production of IL-2 Before and After Depletion of OKT8+ Cells

\begin{tabular}{|c|c|c|c|c|c|c|c|c|c|}
\hline Patient & $\begin{array}{l}\text { Age, } \\
\text { race* }\end{array}$ & $\begin{array}{l}\text { Disease } \\
\text { duration }\end{array}$ & Organ involvementł & Anti-DNA & $\mathrm{CH} 50$ & Cryoglobulins & $\begin{array}{l}\text { Prednisone } \\
\text { dose }\end{array}$ & IL-2. PBM & OKT8- \\
\hline & & $y r$ & & & & $m g / d l$ & & & $\mathrm{U} / \mathrm{ml}$ \\
\hline \multicolumn{10}{|l|}{ Group I§ } \\
\hline M.H. & $28, \mathrm{H}$ & 7 & 0 & 0 & 960 & 4.5 & 0 & 6 & 11 \\
\hline L.R. & $38, \mathrm{C}$ & 18 & 0 & 40 & 640 & 2 & 0 & 5 & 11 \\
\hline V.J. & $50, \mathrm{H}$ & 10 & 0 & 0 & 640 & NDT & 0 & 11 & 207 \\
\hline C.S. & $28, \mathrm{H}$ & 5 & $\mathrm{~A}, \mathrm{Al}$ & 10 & 960 & 5 & 7.5 & 8 & 160 \\
\hline R.R. & $27, \mathrm{H}$ & 4 & A, Sy & 320 & 480 & 11 & 4 & 16 & 128 \\
\hline \multicolumn{8}{|c|}{ Average IL-2 production of group I \pm SEM" } & $9.2 \pm 1.6$ & $103.4 \pm 35.3$ \\
\hline \multicolumn{10}{|l|}{ Group II } \\
\hline H.M. & $32, \mathrm{H}$ & 11 & Sk, Al, V & 40 & 240 & NDI & 5. & 4 & 5 \\
\hline M.G. & $29, \mathrm{H}$ & 3 & Sk, Al, Sy & 0 & 480 & 2 & 2.5 & 4.5 & 25 \\
\hline R.C. & $34, \mathrm{H}$ & 4 & Sk, Al, V, A & 0 & 80 & 5 & 7.5 & 6.0 & 35 \\
\hline R.V. & $25, \mathrm{~B}$ & 1 & Sk, S, P, Sy & 0 & 960 & 2 & 15 & 25 & 38 \\
\hline J.S. & $24, \mathrm{H}$ & 6 & A, Sk, V, F, Sy & 0 & NDI & 18.5 & 5 & 24 & 32 \\
\hline G.H. & $35, \mathrm{H}$ & 0.4 & $\mathrm{~A}, \mathrm{~S}, \mathrm{P}, \mathrm{Bl}, \mathrm{F}, \mathrm{Sy}$ & 40 & 240 & NDI & 5 & 4 & 19 \\
\hline F.D. & $27, \mathrm{~B}$ & 2 & A, K, S, P, NP, F, Sy, O & 0 & 960 & 10 & 4 & 4.6 & 21 \\
\hline M.E. & $23, \mathrm{H}$ & 8 & $\mathrm{~K}, \mathrm{~S}, \mathrm{O}$ & 20 & 240 & 10 & 7.5 & 17 & 169 \\
\hline W.C. & $33, \mathrm{~B}$ & 8 & $\mathrm{~A}, \mathrm{Al}, \mathrm{K}$ & 80 & 960 & 6 & 20 & 1.8 & 13.6 \\
\hline C.R. & $27, \mathrm{H}$ & 1.7 & K, F, Sy & 160 & 80 & 31 & 15 & 4 & 6 \\
\hline N.J. & $42, C$ & 9 & Sk, V, Sy & 0 & 80 & 3.5 & 15 & 2.8 & 31.6 \\
\hline H.E. & $27, \mathrm{H}$ & 4 & Sk, K, S, P & 320 & 160 & 10 & 10 & 8.0 & 17 \\
\hline M.J. & $27, \mathrm{~B}$ & 7 & Sk, V, Bl, Sy & 10 & 640 & 4.5 & 30 & 8.5 & 42 \\
\hline G.S. & $19, \mathrm{C}$ & 2 & Sk, K, Bl, Sy & 160 & 80 & 26 & 3 & 27.0 & 93 \\
\hline G.E. & $32, \mathrm{H}$ & 1 & $\mathrm{~A}, \mathrm{Sk}, \mathrm{Al}, \mathrm{V}, \mathrm{K}$ & 0 & 640 & 5 & 15 & 13 & 23 \\
\hline G.G. & $19, \mathrm{H}$ & 0.5 & A, Sk, V, F, Sy & 80 & 160 & 17 & 15 & 23 & 64 \\
\hline \multicolumn{8}{|c|}{ Average IL-2 production of group II \pm SEM" } & $11.0 \pm 2.2$ & $39.6 \pm 16$ \\
\hline \multicolumn{8}{|c|}{ Average IL-2 production of 19 normals \pm SEM" } & $33.8 \pm 5.6$ & $40.9 \pm 6.7$ \\
\hline
\end{tabular}

Values for anti-DNA are expressed as the reciprocal of the titer. Normal values for anti-DNA are $<1: 10$, for serum complement $480-960 \mathrm{U}$, or cryoglobulins $<3 \mathrm{mg} / \mathrm{dl} .{ }^{*} \mathrm{H}$, Hispanic; C, Caucasian, B, Black. $\ddagger$ A, arthritis; S, serositis; K, renal disease; Sk, mucocutaneous lesions; V, vasculitis; Bl, hematologic abnormality, NP, neuropsychiatric disease; M, myositis; P, pulmonary involvement; Sy, systemic and constitutional symptoms; F, fever; O, other. §Grouped according to number of organ systems involved. "SEM, standard error of the mean. I ND, not done.

Other reagents. Purified human IL-2 was obtained from ElectroNucleonics, Inc., Silver Spring, MD. Standard rat crude IL-2 was prepared by stimulating rat splenocytes with concanavalin A (Miles Yeda, Rehovot, Israel) $10 \mu \mathrm{g} / 4 \times 10^{6}$ cells per milliliter for $48 \mathrm{~h}$. Supernates were harvested, filtered, and frozen until use.

Two-color immunofluorescence staining. Two protocols were used, staining with either fluorescein isothiocyanate (FITC) and X-rhodamine or FITC and phycoerythrin (PE) combinations. All steps were carried out at $4^{\circ} \mathrm{C}$ and all incubations were for $30 \mathrm{~min}$. The cells were washed twice between each incubation, except where noted, with cold media containing $0.1 \%$ sodium azide and $0.5 \%$ bovine serum albumin. $20 \mu \mathrm{l}$ of a saturating concentration of monoclonal antibody was added to 1 $\times 10^{6}$ pelleted peripheral blood mononuclear cells (PBM) and mixed. When X-rhodamine was used, the first antibodies were either anti-Ia, anti-Tac, or biotinylated HNK-1. The cells were labeled red by sequential incubations with $20 \mu \mathrm{l}$ of biotinylated goat anti-mouse immunoglobulin G (IgG) (Vector Laboratories, Inc., Burlingame, CA; 1:30 dilution) and rhodamine 600-Avidin (Vector; 1:40 dilution). When PE was employed, we stained with fluorescein-conjugated antiIa. The other antibodies were stained green with $20 \mu$ l of fluoresceinconjugated sheep anti-mouse IgG (Cappel Laboratories, Inc., Cochranville, PA; 1:20 dilution). In all cases, the cells were incubated for 15 min with $20 \mu$ l of mouse serum (1:10 dilution), to block untreated sites, before adding $5 \mu \mathrm{l}$ of the fluorescein or PE-conjugated monoclonal antibodies. In control groups, we substituted mouse IgG ascites fluid (Bethesda Research Laboratories) for the monoclonal antibodies.

Two-color flow cytometry. The two-color immunofluorescence experiments with FITC and X-rhodamine were analyzed with the use of a dual-laser fluorescence-activated cell sorter (FACS IV, Becton, Dickinson FACS Systems, Becton, Dickinson \& Co., Sunnyvale, CA). FITC and X-rhodamine were excited by using $300 \mathrm{~mW}$ of $488-\mathrm{nm}$ light (argon laser) and $175 \mathrm{~mW}$ of 568-nm light (krypton laser). Fluorescence emission at $90^{\circ}$ relative to the laser beams was split by a $560-\mathrm{nm}$ dichroic mirror. Green light passed through the mirror and $520-\mathrm{nm}$ dichroic and 530-nm glass long-pass barrier filters into a photomultiplier tube. Red light was reflected at $90^{\circ}$ and passed through a $625 \pm 25-\mathrm{nm}$ band-pass filter. Log amplifiers were used to display the fluorescence data. The two-color protocols with FITC and PE were analyzed on an Ortho $50 \mathrm{H}$ Cytofluorograph (Ortho Diagnostic Systems, Inc., Westwood, MA) equipped with a 2150 computer (Data General, Los Angeles, CA). The mirror and filters were the same as those above except for a $575 \pm 15-\mathrm{nm}$ band pass to collect PE fluorescence. Linear amplifiers were used here.

Dead cells, erythrocytes, platelets, and monocytes were excluded from analysis by gating on the lymphocyte cluster using forward light scatter on the FACS IV or axial extinction and $90^{\circ}$ light scatter on 
the Ortho $50 \mathrm{H}$. The total percent positive refers to the percent of 5,000 lymphocytes with fluorescence $>99 \%$ of the background control. The fraction of the subpopulation that double-labeled was calculated as follows: \% double-labeled $=$ (\% of lymphocytes bearing two colors)/ (\% of lymphocytes bearing one color) $\times 100$.

Cell separation techniques. Venous peripheral blood cells from SLE patients and paired healthy controls were separated on a FicollHypaque density gradient and mononuclear cells (PBM) were washed three times and separated by cell sorting or by panning. Both methods gave similar results and were used interchangeably.

For cell sorting, PBM from either normal donors or lupus patients were labeled with monoclonal antibodies for $30 \mathrm{~min}$ on ice. The antibodies used were OKT8, OKT4, and HNK-1 (Leu 7). After washing twice with cold RPMI-1\% fetal calf serum, the cells were resuspended in FITC-conjugated goat-antimouse IgG (Cappel Laboratories, Inc.) and kept for 30 min on ice, washed once, and sorted.

Cell sorting was performed on a fluorescence-activated cell sorter (FACS IV or Cytofluorograph $50 \mathrm{H}$ ). In addition, the percent of positive lymphocytes with more intense fluorescence than $99 \%$ of the background control was used to calculate the OKT4 to OKT8 ratio for both normals and patients. For the background control, a nonspecific mouse IgG ascites fluid (Bethesda Research Laboratories) was substituted for the first antibody. The purity of sorted cells was $>97 \%$.

The second method we used to isolate human mononuclear cell populations was by panning as described by Engleman et al. (11). By this method, we depleted PBM of OKT8+ or Leu 7 (HNK-1)+ subsets. Briefly, PBM, previously depleted of monocytes by adherence on plastic petri dishes, were incubated with OKT8 (20 $\mu \mathrm{g}$ of antibody per $3 \times 10^{7} \mathrm{PBM}$ ), or Leu 7 (50 $\mu \mathrm{g}$ of antibody per $3 \times 10^{7} \mathrm{PBM}$ ) on ice for $20 \mathrm{~min}$, washed, and incubated on petri dishes coated with goat antimouse IgG $(10 \mu \mathrm{g} / \mathrm{ml})$ for $2 \mathrm{~h}$ at $4^{\circ} \mathrm{C}$. The nonadherent, OKT8-, or Leu 7-, lymphocytes were removed by three gentle washings and the adherent, OKT8+ cells were removed with a rubber policeman. Viability was assessed with trypan blue $(>98 \%)$. The harvested negative populations were restained and, when analyzed with the FACS, there were $<4 \%$ OKT $8+$ lymphocytes and $<0.5 \%$ Leu $7+$ cells, respectively. The positively selected, adherent cells contained $<1 \%$ monocytes stained by Mo.2.

In vitro IL-2 production and assay. In that we had previously found that stimulation of cells with both phytohemagglutinin (PHA) and Daudi cells, a lymphoblastoid cell line, resulted in at least 10 -fold higher IL-2 values at $24 \mathrm{~h}$ of culture than with PHA alone (8), this procedure was used mostly in this study. Briefly, $2 \times 10^{6}$ lymphocytes per milliliter were co-cultured with equal amounts of Daudi cells, and $0.1 \%$ bacto phytohemagglutinin M (PHA-M), in RPMI 1640 supplemented with $5 \%$ fetal calf serum, $2.0 \mathrm{mM} \mathrm{L}$-glutamine and $10 \mu \mathrm{g} / \mathrm{ml}$ gentamicin. After $24 \mathrm{~h}$, supernatants were collected and checked for IL-2 activity in a proliferation assay that used CTLL cells, a murine IL-2-dependent cell line. IL activity (expressed as units per milliliter) was calculated by probit analysis using as reference a standard rat IL2 preparation.

In some experiments, positively selected OKT8+ cells were harvested from panning trays, added to equal amounts of OKT8-depleted PBM, and stimulated to produce IL-2 by a 24-h incubation with $1 \%$ PHA-M.

Production of a soluble IL-2 inhibitory factor. Positively selected cells were adjusted to $2 \times 10^{6} / \mathrm{ml}$ in culture medium and incubated for $18 \mathrm{~h}$ at $37^{\circ} \mathrm{C}$ in $5 \% \mathrm{CO}_{2}$. After this, the cells were spun, and supernatants were harvested and stored frozen at $-20^{\circ} \mathrm{C}$.

\section{Results}

Effect of depletion of OKT8+ cells on IL-2 production in vitro. We measured production of IL-2 by PBM of SLE patients and paired controls after stimulation with PHA and Daudi cells for $24 \mathrm{~h}$ (Fig. 1). In agreement with our previous results, levels of IL-2 in SLE were markedly decreased (mean \pm SEM: $12.4 \pm 1.8$

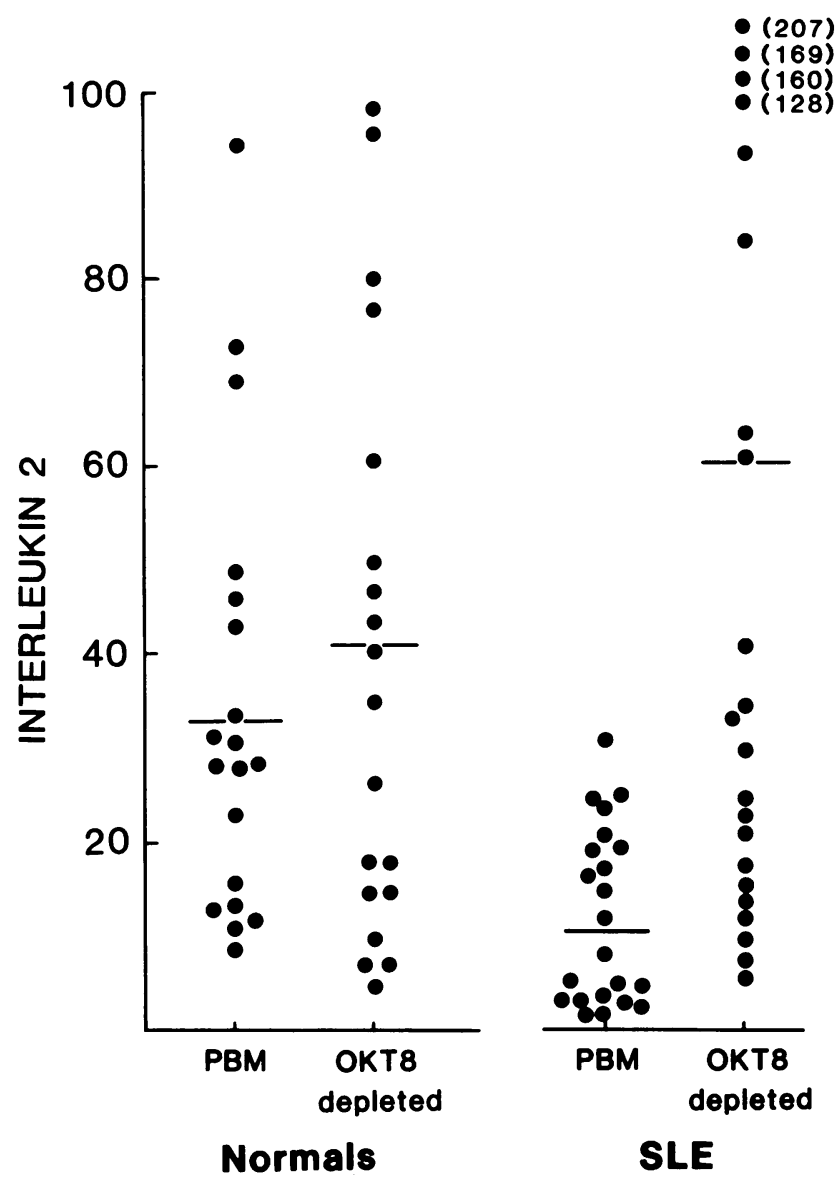

Figure 1. In vitro correction of IL-2 production (U/ml) by PBM from SLE patients after removal of OKT8+ cells. $2 \times 10^{6} / \mathrm{ml}$ PBM were co-cultured with $2 \times 10^{6} / \mathrm{ml}$ Daudi cells and $1 \%$ PHA for $24 \mathrm{~h}$. OKT $8+$ cells were removed by cell sorting or by panning. The patients with IL-2 values between 128 and $207 \mathrm{U} / \mathrm{ml}$ after OKT8+ cell depletion were V.J., M.E., R.R., and C.S. (see Table I).

$\mathrm{U} / \mathrm{ml}$ vs. $33.8 \pm 5.6 \mathrm{U} / \mathrm{ml}$ in controls). Depletion of OKT8+ cells in SLE either by cell sorting or by panning corrected this defect. IL-2 levels in SLE were increased two- to fivefold in 19 of the 21 patients studied and values increased to the normal or above the normal range. Depletion of OKT8+ cells in normal controls did not significantly increase IL-2 production (Fig. 1), although this procedure did result in a twofold elevation in five subjects. Depletion of OKT4+ cells abolished almost completely IL-2 production in all subjects studied. This was expected in that OKT4+ cells are the principal producers of IL-2 in this system (12).

The SLE patients studied were grouped by disease activity (Table 1). In both groups IL-2 values were depressed to $\sim 33 \%$ of normal. After OKT8 (Leu 2)+ cell depletion, the mean IL2 value in both groups was increased, but the IL-2 production in the inactive patients was significantly higher than in the active group $(103.4 \pm 35.3 \mathrm{U} / \mathrm{ml}$ as compared with $39.6 \pm 16$ $\mathrm{U} / \mathrm{ml} ; P=0.025$ by Students $t$ test). Three of the five inactive patients had IL-2 values above the normal range, whereas only 1 of the 16 active patients had an IL-2 value in this high range. Although there was no correlation between the prednisone does and individual IL-2 values, all patients whose IL-2 values rose above normal range after OKT8+ cell removal were receiving not more than $7.5 \mathrm{mg}$ of prednisone. 
Table II. Characterization of Lymphocyte Subsets in SLE by Double-label Flow Cytometry

\begin{tabular}{|c|c|c|c|c|c|c|}
\hline \multirow[b]{2}{*}{ Lymphocyte subset } & \multicolumn{2}{|l|}{ Total } & \multicolumn{4}{|c|}{ Subset double-labeled ${ }^{*}$} \\
\hline & Normal $(n=13) \ddagger$ & $\operatorname{SLE}(n=15)$ & Normal & $(n)$ & SLE & $(n)$ \\
\hline Leu $2+$ & $\begin{array}{l}25.5 \pm 2.1 \S \\
{[587 \pm 12.3]^{\|}}\end{array}$ & $\begin{array}{l}29.5 \pm 2.5 \\
{[395 \pm 9.9]}\end{array}$ & & & & \\
\hline Leu $2+$, la + & & & $\begin{array}{c}6.2 \pm 1.2 \\
{[36.4 \pm 0.4]}\end{array}$ & (13) & $\begin{array}{c}19.3 \pm 3.0 \\
{[76.2 \pm 2.3]}\end{array}$ & $(15) \pi$ \\
\hline Leu 2, Tac+ & & & $\begin{array}{c}0.5 \pm 0.1 \\
{[2.9 \pm 0.003]}\end{array}$ & (13) & $\begin{array}{c}2.6 \pm 0.7 \\
{[10.3 \pm 0.1]}\end{array}$ & $(15)^{* *}$ \\
\hline Leu 2, Leu 7+ & & & $\begin{array}{c}27.8 \pm 3.7 \\
{[163.2 \pm 6.0]}\end{array}$ & (3) & $\begin{array}{c}28.5 \pm 3.9 \\
{[112.6 \pm 4.4]}\end{array}$ & (8) \\
\hline Leu 3+ & $\begin{array}{l}39.5 \pm 3.2 \\
{[908 \pm 29.1]}\end{array}$ & $\begin{array}{l}25.1 \pm 2.8 \\
{[336 \pm 9.4]}\end{array}$ & & & & \\
\hline Leu 3, Ia+ & & & $\begin{array}{c}2.2 \pm 0.7 \\
{[19.9 \pm 0.14]}\end{array}$ & (6) & $\begin{array}{c}8.4 \pm 1.5 \\
{[28.2 \pm 0.4]}\end{array}$ & 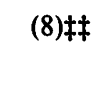 \\
\hline Leu 3, Tac+ & & & $\begin{array}{c}1.2 \pm 0.4 \\
{[10.9 \pm 0.04]}\end{array}$ & (4) & $\begin{array}{c}2.3 \pm 0.5 \\
{[7.7 \pm 0.04]}\end{array}$ & (7) \\
\hline Leu 3, Leu 7+ & & & $\begin{array}{c}3.9 \pm 1.1 \\
{[35.4 \pm 0.4]}\end{array}$ & (4) & $\begin{array}{c}5.2 \pm 1.4 \\
{[17.5 \pm 0.3]}\end{array}$ & (7) \\
\hline
\end{tabular}

* The mean \pm SEM total lymphocyte count was $2,300 \pm 110$ in normals and $1,340 \pm 220$ in SLE. The mean \pm SEM percentage of total lymphocytes stained with the following antibodies in normal controls and SLE were: la+ $15.5 \pm 2.1$ vs. $19.3 \pm 2.3$; anti-Tac $1.0 \pm 0.3$ vs. $2.1 \pm 0.6$; Leu 7

$15.7 \pm 1.6$ vs. $18.0 \pm 2.2$. $¥$ Parentheses indicate the number of subjects studied. $\S$ Values $\pm S E M$ throughout the table are percent positive cells.

"Values \pm SEM in brackets are absolute counts of positive cells. $P$ values using the Wilcoxon rank sum test to compare normals and SLE were:

I $P<0.002 ; \quad$ ** $P<0.007 ; \quad \ddagger \ddagger P<0.02$.

Phenotype of SLE T8+ lymphocytes. Next, we analyzed the phenotype of the OKT8+ cells in SLE as compared with normals (Table II). The mean percentage of OKT8 (Leu 2)+ cells was slightly but not significantly increased in SLE. Doublelabeling studies revealed a three- to fourfold increase of $T$ cells bearing Ia markers in SLE, a finding that suggests activated T cells in this disease. As a control, we compared markers coexpressed by OKT8 (Leu 2)+ cells with those on OKT4 (Leu $3)+$ cells. Both Leu $2+$ Ia + and Leu 3+ Ia+ lymphocytes were increased in SLE in comparison with normals (Table II). The Leu $2+\mathrm{Ia}+$ cells were significantly higher than Leu $3+$ Ia + cells $(19.3$ vs. $8.4, P<0.01$ by the Wilcoxon rank sum test). However, a similar pattern was seen in normals. The percentage of lymphocytes with IL-2 receptors detectable with the monoclonal antibody Tac was small, but significantly increased in SLE over normal controls. In both normals and SLE there were $\sim 30 \%$ of Leu $2+$ cells that co-expressed the Leu 7 marker.

SLE OKT8+ mononuclear cells actively suppress $I L-2$ production. As illustrated in Table II, SLE patients had decreased percentages of OKT4+ cells. We considered whether the increase in IL-2 production after OKT8 (Leu 2) depletion might be due to a relative enrichment of IL-2 producer cells. Autologous add-back experiments excluded this possibility. PBM from six patients and five normals were stimulated to produce IL-2. As before, removal of OKT8+ cells corrected defective IL-2 production in SLE. Adding back an equal number of autologous SLE OKT8+ cells suppressed IL-2 production by $60 \%$, but adding back autologous OKT $8+$ to normal OKT8 depleted cells had no inhibitory effect (Table III).

The finding that removal of OKT8+ cells increased IL-2 values in SLE could be explained by active inhibition or by passive absorption of newly released IL-2. The latter explanation was unlikely for the following reasons. As shown in Table II, $3.2 \%$ of SLE lymphocytes had detectable IL-2 receptors. These lymphocytes stained weakly with anti-Tac (13) in contrast to PBM from normals, which stained brightly $48 \mathrm{~h}$ after stimulation with PHA (results not shown). Moreover, pretreatment of standard concentrations of human IL-2 with freshly prepared SLE PBM did not decrease IL-2 activity.

In addition, we have obtained evidence that the OKT8inhibitory subset releases a soluble factor mediating this effect. OKT8+ cells from three SLE patients and one normal were adjusted to $2 \times 10^{6} / \mathrm{ml}$ and incubated for $18 \mathrm{~h}$ at $37^{\circ}$. The supernatants were harvested and tested for effects on the IL-2

Table III. Suppression of IL-2 Production by Autologous OKT8+ Cells in SLE*

\begin{tabular}{llll}
\hline & & \multicolumn{1}{l}{ IL-2 production } \\
\cline { 3 - 4 } Cells & Add-back & Normal $(n=5)$ & $\operatorname{SLE}(n=6)$ \\
\hline & & $U / m l$ & $U / m l$ \\
PBM & & $36.5 \pm 10.0$ & $19.9 \pm 6.1$ \\
OKT8-depleted & None & $41.3 \pm 11.7$ & $91.2 \pm 32.1$ \\
OKT8-depleted & OKT8+ & $54.2 \pm 16.0$ & $46.7 \pm 22.3$ \\
& & & \\
\hline
\end{tabular}

* $0.9 \times 10^{5}$ PBM or OKT8-depleted cells were stimulated with PHA $0.1 \%$ and allogeneic cells for $24 \mathrm{~h}$ and the supernatants were assayed for IL-2. In add-back experiments, $0.9 \times 10^{5}$ positively selected cells of either normal or SLE donors were mixed with equal numbers of autologous OKT8-depleted cells. 
Table IV. Effect of Supernatants from

OKT8+ Cells on IL-2 Production and Activity

\begin{tabular}{lll}
\hline & \multicolumn{2}{l}{ Percent of control } \\
\cline { 2 - 3 } Donor of OKT8+ supernatant & IL-2 production* & IL-2 activitył \\
\hline & $\%$ & $\%$ \\
Normal control & 116 & 123 \\
SLE 1 & 40 & 115 \\
SLE 2 & 40 & 110 \\
SLE 3 & 49 & 91 \\
\hline
\end{tabular}

* PBM from two normal donors were stimulated with PHA $1 \%$ for $24 \mathrm{~h}$ and the mean value of IL-2 produced was $29.3 \mathrm{U} / \mathrm{ml}$. This value was the baseline for assessing the effect of a 1:15 supernatant of OKT8+ cells. Values calculated as explained in footnote to Table III. ¥ Similar concentrations of supernatant were added to CTLL cells incubated with serial twofold dilutions of purified human IL-2 starting with $50 \mathrm{U} / \mathrm{ml}$.

production of allogeneic normal lymphocytes stimulated by PHA. Table IV shows that at a 1:15 dilution, supernatants of SLE OKT $8+$ cells inhibited IL-2 production by $>50 \%$. These supernatants did not block IL-2 activity inasmuch as they had no inhibitory effect on the response of the CTLL cell line to purified human IL-2 (Table IV). These results were repeated in six additional experiments where the PBM were derived each time from a different normal donor.

Depletion of HNK-1 (Leu 7)+ cells. Besides reacting with T cytotoxic/suppressor cells, the OKT8 monoclonal antibody reacts with $\sim 30 \%$ of "large granular lymphocytes" isolated by Percoll gradient centrifugation (14), or with OKM-1+ lymphocyte-sized cells isolated by flow cytometry (15). Both methods of separation enrich for cells whose functional activities include cytotoxic and immunoregulatory effects (16). The majority of cells in the OKM1+ fraction react with Leu 7 (HNK-1), a monoclonal antibody which has been associated with natural killer cells (17). Therefore, we considered the possibility that

Table V. Enhancement of IL-2 Production* in SLE by Depletion of Leu 7+ and OKT8+ Cells

\begin{tabular}{llll}
\hline & \multicolumn{1}{l}{ IL-2 } & & \\
\cline { 2 - 4 } & PBM & OKT8-depleted & Leu 7-depleted \\
\hline & & $U / m l$ & $U / m l$ \\
Experiment 1 & & & \\
Normal & 45 & 79 & 91 \\
SLE 1 & 11 & 52 & 37 \\
SLE 2 & 21 & 85 & 69 \\
Experiment 2 & & & \\
Normal & 60 & 98 & 112 \\
SLE 3 & 19 & 128 & 112 \\
SLE 4 & 16 & 156 & 64 \\
\hline
\end{tabular}

* IL-2 was generated by a 24-h incubation of PBM with Daudi cells and $0.1 \%$ PHA.

$¥$ Depletion of OKT8+ and of Leu 7+ was done by panning as described in Methods.
OKM1+, Leu $7+$ cells also might be capable of suppressing IL-2 production in SLE.

Lymphocytes from SLE patients and normal controls were depleted of Leu $7+$ or Leu $2+$ cells by panning and then stimulated to produce IL-2. Table $\mathrm{V}$ illustrates results of two such experiments. As before, depletion of Leu $2 \mathrm{a}+$ cells elevated IL-2 production in SLE. We observed that removal of Leu 7+ cells, in SLE also markedly elevated IL-2 production. In these studies depletion of both Leu $2 \mathrm{a}+$ and Leu $7+$ cells increased IL-2 production in the two normal subjects. Similar results were observed in four experiments using a total of four normals and eight SLE donors. Controls were PBM panned over petri dishes coated with goat anti-mouse antibody without prior incubation with monoclonal antibody. This procedure did not enhance IL-2 production.

Possible increased sensitivity of SLE IL-2 producer cells to suppressive signals. To characterize further the mechanisms responsible for the IL-2 defect in SLE, we performed allogeneic add-back experiments whereby OKT8 (Leu 2a)+ cells from one SLE donor were added to OKT8-depleted cells from another SLE patient or a normal. We also investigated the effects of OKT8+ cells from normals added to SLE OKT8depleted cells. The results of one of four experiments are shown in Table VI. These studies revealed that although there was autologous suppression as described before, OKT8+ cells from two SLE donors did not suppress IL-2 production by normal OKT8-depleted cells, and in only one case did SLE cells from one donor inhibit the other.

Table VII summarizes the results of the four allogeneic add-back experiments conducted with lymphocytes from eight SLE patients and four normals. Suppression was arbitrarily defined as inhibition of IL-2 production by at least $50 \%$. In only one-third of the experiments did we observe allogeneic inhibition in SLE. Although, as before, OKT8+ cells from

Table VI. Effect of Allogeneic OKT8+ (Leu 2a) Cells Added to OKT8-depleted Lymphocytes*

\begin{tabular}{lrlll}
\hline & \multicolumn{1}{l}{ IL-2 } & & \\
\cline { 2 - 5 } & & \multicolumn{3}{l}{ Donor of OKT8+ cells added } \\
\cline { 3 - 5 } Donor & None & Normal & SLE-1 & SLE-2 \\
\hline & $U / m l$ & $U / m l$ & $U / m l$ & $U / m l$ \\
Normal & & & & \\
PBM & 120 & & & \\
OKT8-depleted & 157 & 181 & 256 & 362 \\
$\begin{array}{l}\text { SLE-1 } \\
\text { PBM }\end{array}$ & & & & \\
OKT8-depleted & 312 & 294 & 91 & 512 \\
$\begin{array}{l}\text { SLE-2 } \\
\text { PBM }\end{array}$ & & & & \\
OKT8-depleted & 256 & 181 & 45 & 91 \\
\hline
\end{tabular}

* $9 \times 10^{5}$ PBM or OKT8-depleted cells were stimulated with PHA $0.1 \%$ and allogeneic cells for $24 \mathrm{~h}$ and the supernatants were assayed for IL-2. In add-back experiments, $0.9 \times 10^{5}$ positively selected OKT8+ cells were mixed with equal numbers of either autologous or allogeneic OKT8-depleted cells and stimulated for IL-2 production as described above. 
Table VII. Summary of Allogeneic Co-culture Studies on the Suppressive* Effects of OKT8+ Cells on IL-2 Production $\ddagger$

\begin{tabular}{|c|c|c|c|c|}
\hline \multirow{2}{*}{\multicolumn{2}{|c|}{ Cell combinations }} & \multicolumn{3}{|c|}{ Number of co-cultures } \\
\hline & & \multirow[b]{2}{*}{ Total } & \multirow{2}{*}{$\begin{array}{l}\text { Number } \\
\text { suppressed }\end{array}$} & \multirow{2}{*}{$\begin{array}{l}\text { Percent } \\
\text { suppressed }\end{array}$} \\
\hline OKT8-depleted & OKT8-added & & & \\
\hline & & $n$ & $n$ & $\%$ \\
\hline SLE & SLE-autologous & 8 & 8 & 100 \\
\hline SLE & SLE-allogeneic & 6 & 2 & 33 \\
\hline SLE & Normal & 6 & 3 & 50 \\
\hline Normal & SLE & 8 & 1 & 12.5 \\
\hline Normal & Normal autologous & 4 & 0 & 0 \\
\hline
\end{tabular}

* Suppression has been defined as at least $50 \%$ inhibition of IL-2 production by $0.9 \times 10^{5}$ cells added to $0.9 \times 10^{5}$ OKT8-depleted cells.

‡ Culture conditions were described in Table IV.

normals did not suppress autologous cells, the addition of these cells suppressed IL-2 production by SLE cells in three of six cases. In only one case, however, did SLE OKT8+ cells suppress IL-2 production in normals. These results suggest that the defect in IL-2 production in SLE not only involved an increased population of suppressive OKT8+ cells, but the producer cells in SLE may be exquisitely sensitive to certain inhibitory signals.

\section{Discussion}

The studies reported here suggest that spontaneously activated blood mononuclear suppressor cells may be responsible for decreased IL-2 production in vitro in SLE. Removal of either OKT8 (Leu 2)+ or Leu 7+ mononuclear cells enhanced IL-2 values to normal or above normal values. The inhibition of IL-2 production was due to active suppression and not passive absorption of newly released lymphokine. This conclusion was based upon the observations that $(a)<2 \%$ of SLE lymphocytes expressed IL-2 receptors; (b) SLE lymphocytes were unable to absorb exogenous human IL-2; and $(c)$ cell-free supernatants from SLE OKT8 (Leu 2)+ cells also inhibited IL-2 production by lymphocytes from normal donors without inhibiting IL-2 activity. In mice, Lyt $2+$ cyclophosphamide-sensitive lymphocytes produce a similar soluble, non-major histocompatibility locus restricted suppressive factor (18).

The defective IL-2 production in SLE is complex. On one hand, there appears to be increased sensitivity of the producer cells to inhibitory signals. Evidence for this was provided by the finding that OKT8 (Leu 2a)+ cells from normals could significantly suppress IL-2 production in SLE although these cells had no effect upon autologous lymphocytes. However, because SLE-derived suppressive factors consistently inhibited IL-2 production by normal lymphocytes, one could argue that the interaction of normal or SLE OKT8+ cells with other cells present in the SLE-derived cell suspensions may be required for suppression to occur. This requirement can be bypassed by a cell-free suppressive factor. These possibilities are currently under investigation.

Physiologic inhibitory mechanisms for IL-2 production in humans have been described. It has been reported that prostaglandin $\mathrm{E}_{2}$ can inhibit IL-2 production either by a direct effect on the producer $\mathrm{T}$ cell (19) or by stimulating a suppressor
T cell (20). There is evidence that concanavalin A-induced T suppressor cells inhibit IL-2 production (21) and Puck and Rich (22) have identified OKT8 (Leu 2a) + cells activated by pokeweed mitogen in vitro that suppress IL-2 production. Recently, Kasahara et al. (23) have reported on a large granular lymphocyte subset that suppressed IL-2 production (23).

Previously, we could not elevate IL-2 production in SLE to levels found in normal controls by removal of monocytes, or in the presence of exogenous interleukin-1, or indomethacin (24). These results can now be explained in view of the experiments reported here where at least one of the IL-2 suppressors is an OKT8 (Leu 2a)+ subset. In SLE this subset appears to be spontaneously activated in vivo in that $33 \%$ expressed Ia markers. However, direct proof that the OKT8 (Leu 2a)+ suppressor is also an Ia + cell is still needed.

There are other reports of spontaneously activated blood mononuclear cells in SLE. We have described spontaneously proliferating cells (25) and others have reported evidence of activated $T$ cells in this disorder (26). Because removal of suppressor cells from the cell suspensions of some normal donors also elevated IL-2 production, it is likely that the findings in SLE reflect augmentation of a physiologic regulatory mechanism instead of an aberrant phenomenon.

Although the monoclonal antibody OKT8 (Leu 2) labels T suppressor cells, the cell type inhibiting IL-2 secretion requires further characterization. The additional finding that removal of Leu 7 (HNK-2)+ cells enhances IL-2 production in SLE and in normals also, suggests that cells from a non-T, non-B, third mononuclear population (16) might be involved in IL-2 regulation. In addition to their well-known cytotoxic properties, these cells regulate hematopoiesis in mice (27), and suppress granulocyte (28) and antibody production (29) in humans. Inasmuch as $33 \%$ of OKT8 (Leu 2a)+ cells bear the HNK-1 marker, it is possible that this is one of the subsets responsible for the suppression we have described.

Unregulated immunoglobulin production in SLE has been considered to be a result of inadequate suppression. There is abundant evidence of impaired $\mathrm{T}$ suppressor cell activity in SLE $(2,3,30)$ although there are some workers who reported that suppressor cell activity is intact $(6,31)$. Our observation of excessive suppressor cell activity may, at first glance, appear paradoxical, but not if one can ultimately distinguish cells that inhibit production of immunoglobulin from cells that suppress IL-2 production.

Excessive suppression of IL-2 production may not be a feature unique to SLE. A similar defect in IL-2 production in vitro has been reported in recipients of bone marrow transplants (32) and decreased mitogenic responsiveness in lepromatous leprosy may also be caused by suppression of IL-2 production (33).

The mechanism responsible for activation of suppressor cells in SLE is a matter of speculation. The finding of above normal IL-2 values after removal of OKT8+ cells in some patients with inactive disease may yield a clue. Most of the abnormalities in cell mediated immunity in SLE fluctuate with disease activity and probably, reflect secondary manifestations of the disease rather than significant pathogenetic events. If studies on larger numbers of inactive patients and family members will reveal the abnormal IL-2 production we have described here, this defect may be added to the list of hormonal and genetic factors that may be important in the pathogenesis of SLE. 


\section{Acknowledgments}

The authors wish to thank Mrs. Liddia Balisi, Mr. Barry Udis, and Mrs. Lillie Hsu for excellent technical help and Mrs. Nancy Lutz for skillful secretarial assistance.

This work was supported in part by grants from the National Institutes of Health (AM-29846 and AM-32569), the Department of Adult Health Services of the State of California, and the Arthritis Foundation.

\section{References}

1. Morimoto, C., E. L. Reinherz, S. F. Schlossman, P. H. Schur, J. A. Mills, and A. D. Steinberg. 1980. Alterations in immunoregulatory $\mathrm{T}$ cell subsets in active systemic lupus erythematosus. J. Clin. Invest. 66:1171-1174.

2. Abdou, N. I., A. Sagawa, E. Pascual, J. Herbert, and S. Sadeghee. 1976. Suppressor T cell abnormality in idiopathic systemic lupus erythematosus. Clin. Immunol. Immunopathol. 6:192-199.

3. Bresnihan, B., and H. G. Jasin. 1977. Suppressor function of peripheral blood mononuclear cells in normal individuals and patients with systemic lupus erythematosus. J. Clin. Invest. 59:106-116.

4. Smolen, J., T. Chused, W. Leiserson, J. R. Reeves, D. Alling, and A. D. Steinberg. 1982. The heterogeneity of immune regulatory $T$ cell subsets in systemic lupus erythematosus: Correlations with clinical features. Am. J. Med. 72:783-790.

5. Bakke, A. C., P. A. Kirkland, R. C. Kitridou, F. P. Quismorio, T. Rea, G. R. Ehresmann, and D. A. Horwitz. 1983. T lymphocyte subsets in systemic lupus erythematosus. Arthritis Rheum. 26:745750.

6. Delfraissy, J. F., P. Segond, P. Galanaud, C. Wallon, P. Massias, and J. Dormond. 1980. Depressed primary in vitro antibody response in untreated systemic lupus erythematosus ( $T$ helper cell defect and lack of defective suppressor cell function). J. Clin. Invest. 66:141-148.

7. Kurnick, J. T., K. O. Gronvik, A. K. Kimura, J. B. Lindblom, V. T. Skoog, O. Sjoberg, and H. Wigzell. 1979. Long term growth in vitro of human $\mathrm{T}$ cell blasts with maintenance of specificity and function. J. Immunol. 122:1255-1260.

8. Linker-Israeli, M., A. C. Bakke, R. C. Kitridou, S. Gendler, S. Gillis, and D. A. Horwitz. 1983. Defective production of interleukin 1 and interleukin 2 in patients with systemic lupus erythematosus (SLE). J. Immunol. 130:2651-2655.

9. Varela, J. A., and D. Alarcon-Segovia. 1982. Decreased production of and response to interleukin 2 by cultured lymphocytes from patients with systemic lupus erythematosus. J. Clin. Invest. 69:1388-1395.

10. Tan, E. M., A. S. Cohen, J. F. Fries, A. T. Masi, D. J. McShane, N. F. Rothfield, J. G. Schaller, N. Talal, and R. J. Winchester. 1982. The 1982 revised criteria for the classification of systemic lupus erythematosus. Arthritis Rheum. 25:1271-1277.

11. Engleman, E. G., C. J. Benike, F. C. Grumet, and R. L. Evans. 1981. Activation of human T lymphocyte subsets: helper and supressor/ cytotoxic $\mathrm{T}$ cells recognize and respond to distinct histocompatibility antigens. J. Immunol. 127:2124-2129.

12. Meuer, S. C., R. E. Hussey, A. C. Penta, K. A. Fitzgerald, B. M. Stadler, S. F. Schlossman, and E. L. Reinherz. 1982. Cellular origin of interleukin 2 (IL-2) in man: Evidence for stimulus restricted IL-2 production by T4+ and T8+ lymphocytes. J. Immunol. 129:10761079.

13. Leonard, W. J., J. M. Depper, T. Uchiyama, K. A. Smith, T. A. Waldmann, and T. A. Greene. 1982. A monoclonal antibody that appears to recognize the receptor for human $\mathrm{T}$ cell growth factor; partial characterization of the receptor. Nature (Lond.). 300:267-269.

14. Ortaldo, J. R., S. D. Sharrow, T. Timonen, and R. B. Herberman. 1981. Determination of surface antigens on highly purified human NK cells by flow cytometry with monoclonal antibodies. $J$. Immunol. 127:2401-2409.

15. Bakke, A. C., G. J. Marshall, M. Kurchin, M. Linker-Israeli, and D. A. Horwitz. 1983. In Intracellular Communications in Leukocyte Function. J. W. Parker and R. L. O'Brien, editors. John Wiley and Sons, Ltd., London. 559-563.

16. Horwitz, D. A., and A. C. Bakke. 1984. The present status of the third mononuclear cell population. Immunol. Today (Amst.). 5: $148-153$.

17. Abo, T., and C. M. Balch. 1981. A differentiation antigen of human $\mathrm{KN}$ and $\mathrm{K}$ cells identified by a monoclonal antibody (HNK1). J. Immunol. 127:1024-1029.

18. Malkovsky, M., G. L. Asherson, B. Stockinger, and M. C. Watkins. 1982. Nonspecific inhibitor released by $T$ acceptor cells reduces the production of interleukin 2. Nature (Ĺand.). 300:652-655.

19. Tilden, A. B., and C. M. Balch. 1982. A comparison of PGE2 effects on human suppressor cell function and on interleukin 2 function. J. Immunol. 129:2469-2473.

20. Chouaib, S., and D. Fradelizi. 1982. The mechanisms of inhibition of human IL-2 production. J. Immunol. 129:2463-2468.

21. Northoff, H., C. Carter, and J. J. Oppenheim. 1980. Inhibition of concanavalin $\mathrm{A}$ induced human lymphocyte mitogenic factor (interleukin 2) production by suppressor T lymphocytes. J. Immunol. 125:1823-1828.

22. Puck, J. M., and R. R. Rich. 1984. Regulatory interactions governing the proliferation of $\mathrm{T}$ cell subsets stimulated with Pokeweed mitogen. J. Immunol. 132:1106-1112.

23. Kasahara, T., J. Y. Djeu, S. F. Dougherty, and J. J. Oppenheim. 1983. Capacity of human large granular lymphocytes (LGL) to produce multiple lymphokines, Interleukin 2, Interferon and colony stimulating factor. J. Immunol. 131:2379-2385.

24. Linker-Israeli, M., D. A. Horwitz, and S. Gillis. 1983. Prostaglandin inhibition of Interleukin 1 and Interleukin 2 production by mononuclear cells in systemic lupus erythematosus. Fed. Proc. 42:1335. (Abstr.)

25. Horwitz, D. A., P. Statsny, and M. Ziff. 1970. Circulating DNA-synthesizing mononuclear leukocytes: I. Increased numbers of proliferating mononuclear leukocytes in inflammatory disease. J. Lab. Clin. Med. 76:391-402.

26. Cohen, P. L., D. A. Litvin, and J. B. Winfield. 1982. Association between endogenously activated $T$ cells and immunoglobulin secreting B cells in patients with active systemic lupus erythematosus. Arthritis Rheum. 25:168-173.

27. Nunn, M. E., R. B. Herberman, and H. T. Holden. 1977. Natural cell mediated cytotoxicity in mice against non-lymphoid tumor cells and some normal cells. Int. J. Cancer. 20:381-387.

28. Hansson, M., and R. Kiessling. 1982. Natural killing of hematopoietic cells. In NK Cells and Other Natural Effector Cells. R. B. Herberman, editor. Academic Press, Inc., New York. 10771084.

29. Tilden, A. B., T. Abo, and C. M. Balch. 1983. Suppressor cell function of human granular lymphocytes identified by the HNK-1 (Leu 7) monoclonal antibody. J. Immunol. 130:1171-1175.

30. Fauci, A. S., A. D. Steinberg, B. F. Haynes, and G. Whalen. 1978. Immunoregulatory aberrations in systemic lupus erythematosus. J. Immunol. 121:1473-1479.

31. Tsokos, G. C., and J. E. Balow. 1982. Suppressor T cells in systemic lupus erythematosus: lack of defective in vitro suppressor cell generation in patients with active disease. J. Clin. Lab. Immunol. 8: 83-90.

32. Azogui, O., E. Gluckman, and D. Fradelizi. 1983. Inhibition of IL-2 production after human allogeneic bone marrow transplantation. J. Immunol. 131:1205-1208.

33. Mehra, V., J. Conwit, A. Rubinstein, and B. C. Bloom. 1982. Activated suppressor T cells in leprosy. J. Immunol. 129:1946-1951. 